\title{
Bringing Justice Closer to the People: An Assessment of the Lagos State (Nigeria) Office of the Public Defender (OPD)
}

\author{
S. Banji Fajonyomi ${ }^{1}$ and A. Dabiri ${ }^{2}$ \\ 1. Department of Public Administration, Lagos State, University, Ojo, Lagos, P.O.BOX 13511, \\ IKEJA, Lagos, Nigeria \\ E-mail: fajonyomib@yahoo.co.uk \\ 2. Lagos State High Courts. Ministry of Justice, Lagos, Nigeria
}

KEYWORDS Public defender; access to justice; Nigeria

\begin{abstract}
Access to justice should not be a privilege of the rich alone. In a country where more than $70 \%$ of its inhabitants live below the poverty line, getting justice to the poor has been a matter of concern. However, there was no visible effort at either the federal or state level until the creation of the Lagos State Office of the Public Defender by the civilian government of Governor Bola Ahmed Tinubu. The Public Defender model that is adopted in Lagos State is patterned after what operates in the United States. The Lagos State OPD, as it is often called, has taken giant steps in making the poor have a feeling of justice at no cost. Despite its achievements, there still exists some pockets of problems that need to be given serious attention if the OPD intends to achieve more.
\end{abstract}

\section{INTRODUCTION}

The preoccupation with the rights of man in history has never been of interest to the majority of governments and people. It has always been the concern of a few. The processes leading to the promulgation of The Universal Declaration of Human Rights in 1948 attest to this. It is the efforts of these individuals that gave birth to the Universal Declaration of Human Rights that provided for equality before the law and access to fair hearing. Articles 7, 8 and 10 of the Bill specifically state that:

All are equal before the law and are entitled without any discrimination to equal protection of the law (Art. 7).

Everyone has the right to an effective remedy by the competent national tribunals for acts violating the fundamental rights granted him by the constitution or by the law (Art. 8)

Everyone is entitled in full equality to a fair and public hearing by an independent and impartial tribunal, in the determination of his rights and obligations and of any criminal charge against him (Art. 10).

Progressively, most countries that are signatories to the United Nations charter have inculcated these clauses into their national constitutions. Boutros Boutros-Ghali, a former Secretary-General of the United Nations, acknowledged this development when he stated that, "It is heartening to see the broad and constructive impact the International Bill of Human Rights has had on international legal thought. The objectives and principles contained in those instruments now find reflection in the constitutions and national legislation of many Member States."(United Nations, 1993: v)

Nigeria, being a member of the United Nations, has similar clauses in her constitution. The 1999 Constitution specifically states in Sections 36(1) that:

In the determination of his civil rights and obligations, including any question or determination by or against any government or authority, a person shall be entitled to a fair hearing within a reasonable time by a court or other tribunal established by law and constituted in such manner as to secure its independence and impartiality.

There have however been few problems militating against the full realisation of the spirit of this clause in many developing countries like Nigeria. According to Du Bois (1994), 'the insistence in the West on confining the quest for human rights to political freedoms and civil liberties, ignoring the economic, social and cultural rights to employment, food, shelter, clothing, education, health and the pursuit of happiness is a subterfuge... It relieves leaders in government and society of responsibility for guaranteeing an equal opportunity for all members of the society to contribute and flourish in that society...."

The above statements indicate that even when rights are granted to individuals without the economic empowerment to pursue or prosecute such rights, such individuals will have 
problems enjoying such rights to the fullest (Rochter, 1998). The right to fair trial and equal access to justice might be difficult when the victim has no money to hire a counsel. In a situation where more than sixty per cent of the citizens live below the poverty level and where legal fees in some instances can become very expensive, many are left with no other option than to face trial without or accept whatever inhuman treatment that is meted unto them without recourse to the law courts.

Another concern in the issue of access to justice is the unusual delay in civil cases that ordinarily could be settled out of court. Matters having to do with the family, landlord tenant relationship could be settled without much delay and without incurring legal costs.

It is in this regard that some governments in both developed and developing countries have established special institutions to assist the poor in enjoying their rights to fair hearing. The Office of the Public Defender is one of those institutions. From advanced democratic states like the United States of America, Australia, Netherlands, among others, to the newly introduced democracies of Eastern Europe like Czech Republic, the right of the poor has been guaranteed and sustained through the public defender system.

In Nigeria, the Lagos State government introduced the Office of the Public Defender in its Ministry of Justice with "responsibility for the provision ... of free legal services and advice to and in respect of persons entitled thereto" (OPD Law, 2003, section 2). The OPD started operation in July 2000, well before this law. This paper reports an empirical research that was conducted to assess the impact of the OPD on the citizens of Lagos State. It primarily tries to determine how far the institution has been able to meet the reasons for its establishment in its short period of existence.

This paper is thus divided into four sections. Section two presents the research methodology that was utilized to extract information for the paper. In section three, the principles and practice of the public defender system are presented with the aim of introducing how it is done in Lagos State. Section four presents and analyses the findings. These include the issue of the number of people that has access to the institution, the level and type of funding available to this institution to carry out its functions and the type of problems inhibiting the institution from performing its role. In the concluding section, the paper advances recommendations, based on international experiences on how to make the Lagos State OPD perform better.

\section{RESEARCH METHODOLOGY}

The population under study consists of 280 residents of Lagos State, irrespective of their state of origin. The population was randomly selected to determine the spread of those that have access to OPD across the former twenty local governments of the state. The data collection instruments used was personal interviews with individuals and officers of the Office of the Public Defender at their headquarters at the Lagos State Government Secretariat, Alausa, and distribution of questionnaires. The first part of the questionnaire contains information about the biodata of respondents to determine not only their age but also their educational qualifications and professional affiliations. The second part of the questionnaire inquires about their awareness, if at all, of the problem of access to justice and the existence of the Office of the Public Defender and its functions. The questionnaire also seeks to find out the roles that all the tiers of government are expected to play in the administration of justice and protection of human rights in general.

\section{Principles and Practice of the Public Defender System}

The Office of the Public Defender in Lagos State is patterned after the American model. The origin of the right to counsel in criminal cases in the United States can be found in the Bill of Rights, enshrined in the 6th Amendment to the U.S. Constitution. The $6^{\text {th }}$ Amendment states that:

In all criminal prosecutions, the accused shall enjoy the right to a speedy and public trial, by an impartial jury of the state and district wherein the crime hall have been committed, which district shall have been previously ascertained by law, and to be informed of the nature and cause of the accusation; to be confronted with the witnesses against him; to have compulsory process for obtaining witnesses in his favour, and to have the assistance of counsel for his defence.

However, it was in the landmark case Alabama v. Powell, that the United States Supreme Court set out the basic principles underlying the constitutional right to assistance of counsel: 
The right to be heard would be, in many cases, of little avail if it did not comprehend the right to be heard by counsel. Even the intelligent and educated layman has small and sometimes no skill in the science of law. If charged with crime, he is incapable, generally, of determining for himself whether the indictment is good or bad. He is unfamiliar with the rules of evidence. Left without the aid of counsel he may be put on trial without a proper charge, and convicted upon incompetent evidence, or evidence irrelevant to the issue or otherwise inadmissible. He lacks both the skill and knowledge adequately to prepare his defense, even though he has a perfect one. He requires the guiding hand of counsel at every step in the proceedings against him. Without it, though he be not guilty, he faces the danger of conviction because he does not know how to establish his innocence [287 U.S. 45, 68-69 (1932)].

Though, the Powell decision applied only to death penalty cases, the principle over the years has been extended, in varying degrees across the states to provide counsel to non-capital indigent defendants, especially when such cases may result in a potential loss of liberty.

\section{Reasons Why There should be a Public Defender System}

Literature abounds on why the public defender system should be encouraged. Moore (2001) has advanced most of the current arguments for the continuation of the public defender system. These are summarized below.

- It is a constitutional right and so it must be sustained.

- The court system cannot function without public defenders

- The adversarial system is the best and most reliable way to achieve

- It protects the innocent from unjust punishment.

- It protects the rights of citizens against the overbearing state.

- The poor should not be disadvantaged relative to the rich when issues of equal protection against state power are at stake.

\section{A Model for Public Defender System?}

- There is a big problem designing a model public defender system based on the fact that each system responds to the stimuli from its environment. This fact has been proved by a research conducted by, the Scottish Office Home Department analysing the public defender system in Canada (The Scottish Office Home Department, 1998). The report concluded that public defenders scheme in Scotland has much to learn from the Canadian experience.

Fabelo (2001) provided what he considered as The Ten Commandments of Public Defense Delivery Systems. According to him,

Poverty is not an excuse to provide less than competent representation. Public defense delivery systems must efficiently and effectively provide high quality, zealous, conflict-free representation to those charged with crimes who cannot afford to hire an attorney. To meet this goal,

Thou shalt...

1. Assure that the public defense function, including the selection, funding, and payment of appointed counsel, is independent.

2. Assure that where the caseload is sufficient, the public defense delivery system consists of both a defender office and the active participation of the private bar.

3. Screen clients for eligibility, then assign and notify counsel of their appointment within 24 hours.

4. Provide counsel sufficient time and a confidential space to meet with the client.

5. Assure counsel's workload matches counsel's capacity.

6. Assure counsel's ability, training, and experience match the complexity of the case.

7. Assure that the same attorney continuously represents the client until completion of the case.

8. Provide counsel with parity of resources with the prosecution and include counsel as an equal partner in the justice system.

9. Provide and require counsel to attend continuing legal education.

10. Supervise and systematically review counsel for quality and efficiency according to nationally and locally adopted standards.

\section{Office of Public Defender in Lagos State}

The office of the Public Defender is a unit of the Ministry of Justice. The ministry is divided into eight sections including the Directorate for Citizens Rights. OPD is an offshoot of the 
Directorate for Citizens Rights, which is divided into five (5) units and one of the units is the OPD. The Directorate for Citizens Rights was established by the State government as part of his administration's policy to give citizens unhindered access to justice and its institutions.

OPD offers free legal services and representation to the poor. It begins its process when petitions are received from citizens on any grievance ranging from unpaid salaries and entitlements, unlawful detention and arrest, breach of contract, estate and land administration, problems between landlord and tenant, problems of custody and welfare of children, unlawful termination of appointments, industrial accident, threat to life, divorce issues, recovery of debt, issues relating to fraud, obtaining money by false pretences and extra-judicial killings. The office also offers representation in both criminal and civil matters in the law courts ranging from stealing, armed robbery, murder, loss of luggage, unlawful possession of firearms, rape, assault/ battery, defamation of character, etc.

Apart from defence functions, it organizes enlightenment programmes to educate members of the public and generate awareness of its activities. This is done through Radio and TV adverts. OPD also publishes and distributes brochures and leaflets in various languages across the state.

As part of its activities, the OPD visits major prisons within Lagos State (Ikoyi, Kirikiri and Badagry) regularly to study the cases of inmates and examine those it can assist either because they have been detained over time without trial or simply because they could not afford the services of a lawyer or did not just have access to any lawyer.

In its five years of existence, according to the Office, the Mediation Centre has received 5,600 petitions at an average of 30 petitions per day. It has succeeded among others in releasing from prison 250 juveniles. It has also helped to collect over N6 million for people who took their cases to them. These settlements involved rents, unpaid salaries, payment for work done etc. Part of the recovery was the payment of $\mathrm{N} 950,000.00$ by a textile company which had been owing its workers. Widows have also been assisted in collecting death benefits. The efforts of the Office in the January $27^{\text {th }} 2002$ Ikeja Military Cantonment bomb blast is also worth mentioning. The OPD collated the names of the dead, injured and missing persons and processed claims on behalf of the victims and their relatives. The efforts of the Office paid off as the Federal Government paid the sum of N500, 000 to relatives of each of the dead victims.

The Lagos State Office of the Public Defender enjoys the support of international agencies in terms of material, financial and training. Prominent among such agencies are the Ford Foundation, the British Directorate for International Development, and the United States Agency for International Development.

\section{ANALYSIS OF THE FINDINGS}

Access to Justice in Nigeria: The general contention in this study is that there exist some pockets of problems as far as access to justice is concerned. The respondents $(57 \%)$ feel that the Federal government is not doing enough. It is correct that the federal government established the Legal Aid Council to assist indigents to have access to counsel in their trials. However, in its Lagos office, there are just two lawyers. This is grossly inadequate if one considers the fact that with a population estimated to be 15 million and the nature of crime for which the city is known.

The efforts of Lagos State government were adjudged okay by $85.75 \%$ of respondents. This may not be unconnected with the activities of the Citizens Mediation Centre of which OPD is a unit. There are 36 lawyers in the unit and 19 of them are trained mediators. The volume of business handled by the office is also a testimony to this fact.

Another dimension to the issue of access to justice is the role of non-governmental agencies. The respondents accorded a high rate of participation to the NGOs. This result may not be unconnected to the role played by these groups during the long period of military rule. Groups such as Campaign for Democracy (CD) and Civil Liberties Organisations (CLO) were prominent in the struggle against unlawful detention and extrajudicial killings during the military era, especially under General Sani Abacha. Though these groups still play similar role, but is no longer as prominent as they used to be then.

Awareness of the Existence of the Office of the Public Defender: One of the problems of major reform institutions in Nigeria is the almost absolute ignorance of their existence. Surprisingly this is not the case with the OPD. Majority of the 
respondents $85.7 \%$ claimed to be aware of its existence. This may not be surprising because at the inauguration of the office, the state government did a lot of public awareness campaigns on local television and radio stations at prime time using popular home video actors. This could probably explain the high percentage of positive response from the question. This result could also be translated into the volume of petitions and cases that the office has had to handle since inception.

\section{CONCLUSIONS}

As a result of the findings reported above, it will not be out of place if efforts are made to reform the OPD in Lagos state. The following recommendations might be useful in this direction.

- There must be increased effort to increase the number of staff in the OPD. This should be in the areas of attorneys, investigators and other supporting administrative staffs.

- A better management structure that will make OPD more independent in terms of administration and finance will go a long way to assist the organisation to be more effective. The recruitment and salary structure should be separated from that of the civil service to be able to attract intelligent attorneys to its fold. It is also recommended that additional remuneration be made available to lawyers in the organisation that have been able to handle near difficult cases successfully as a means of encouraging them against future assignments.

- Apart from the normal brochure listing the activities of the OPD that is currently made available to the public, OPD should design operational manual of its procedure to give the public the required confidence to trust the organisation.

- As it has been proposed in one of its documents, OPD should take the issue of training very seriously. This should cut across the staff of OPD and even the magistrates that handle most of these cases. Overseas training should not be considered expensive; as such exposures will assist the operation of the system in Lagos state.

- The OPD should also embark on further enlightenment campaign to educate the public about its operations. Although, many people claim to be aware of its existence, this may be limited to educated people alone. It was discovered also that the organisation had its material translated into the major languages in the country. This may not however be as sufficient as television adverts and radio jingles it used at the beginning of its operations.

- Lastly, as it is being currently proposed, the OPD should endeavour to make its presence known in all the local governments of the state. Even though OPD has grown from one office when it was established to five today. This may not be enough to cater for the teeming population of Lagos state.

\section{REFERENCES}

Brian Clark. 1997. "Who's afraid of the Public Defender ?" New Law Journal 7th November 1997 p. 1629

Conference 6th November 1997, reported in THE LAWYER 18th November

Du Bois, David Graham. 1994. Racism in the West and its Impact Upon Human Rights, A Paper Submitted to the International conference on Rethinking Human Rights, Malaysia.

Fabelo, T. 2001. "What Policymakers Need to Know To Improve Public Defense Systems." Public Defense Papers From the Executive Sessions on Public Defense. December, Bulletin No. 2.

Lagos State Ministry of Justice. (Not Dated) The Citizens' Mediation Centre.

Lagos State Ministry of Justice. (Not Dated) The Directorate For Citizens' Rights.

Lagos State Ministry of Justice. (Not Dated) Office of the Public Defender. Provider of free legal services to the poor.

Moore, M. H., Daniel and Florence V. Guggenheim. 2001. "Alternative strategies for public defenders and assigned counsel", Paper Prepared for the Executive Session on Public Defense Program in Criminal Justice Policy and Management of the Malcolm Wiener Center for Social Policy, John F. Kennedy School of Government, Harvard University, Cambridge, Massachusetts.

Rashkind, Paul M. 2003. 'Gideon v. Wainwright: A 40th Birthday Celebration and the Threat of a Midlife Crisi," The Florida Bar Journal Volume LXXVII, No. 3.

Rochter, H. 1998. 'Human Rights: Challenges And Obstacles," Development \& Socio-Economic Progress. No. 72 January/March, pp. 33-43. The Guardian (Nigeria) 11th November 1997.

The National Legal Aid \& Defender Association. 2003. Evaluation of the Public Defender Office :Clark County, Nevada. Washington, DC Public Defender Office: Clark County, Nevada. Washington, DC

The Scottish Office Home Department. 1998. "A Literature Review of Public Defender or Staff Lawyer Schemes." Legal Studies Research Findings No. 19 United Nations. 1993. Human Rights. The International Bill of Human Rights. New York: United Nations. 